\title{
Peran Perjanjian Ekstradisi Dalam Penegakan Hukum Tindak Pidana Korupsi di Indonesia
}

\author{
Fauzin \\ Fakultas Hukum Universitas Trunojoyo Madura \\ fauzin34nk@gmail.com
}

Submit: 26-04-2021; Review: 03-06-2021; Terbit: 30-06-2021

\begin{abstract}
The purpose of the study is to determine the role of extradition agreement in law enforcement of corruption in Indonesia. In order to reach the goal, the study applies normative law as the method of study and also secondary and primary as the law instrument. The result of study shows that the challange and problem occur in law enforcement of corruption crime in Indonesia can be measured by the increasing of crime percentage on that act. The easiness of going accross countries become most priority taken by corruptors (status as suspect, defendant or convict) along with his or her assets resulting from corruption. Therefore, in the context of law enforcement in corruption field, the perpetrator of corruption must be sent home to Indonesia and using Indonesian law to judge them. In order to implement it, law enforcement must apply Extradition mechanism while instrument to return assets collected from corruption called mechanism of Mutual Legal Assistance in Criminal Matters (MLA) must take place. Those mechanisms become important for the principals of international law existed in each countries apply soverignty over their territory, so everytime a legal context of suppression applied in a country, this mechanism become the most approriate solution to take.
\end{abstract}

\section{Keywords: Corruption, Extradition, Law Enforcement.}

\begin{abstract}
Abstrak
Tujuan dari kajian ini adalah untuk mengetahui peran perjanjian ekstradisi dalam penegakan hukum korupsi di Indonesia. Guna untuk mencapai tujuan tersebut, maka dalam penelitian ini menggunakan metode penelitian hukum normative dan menggunakan bahan hukum primer dan sekunder. Hasil dari penelitian ini adalah bahwa persoalan dan tantangan dalam penegakam hukum tindak pidana korupsi di Indonesia adalah dengan semakin meningkatnya presentase kejahatan tersebut. Kemudahan dalam berpindah antar negara pelaku tindak pidana korupsi baik yang berstatus tersangka, terdakwa ataupun terpidana sering kali memilih untuk melarikan diri keluar negeri beserta asset-aset hasil korupsi yang dimilikinya. Oleh karena itu dalam rangka penegakan hukum bagi pelaku dengan cara memulangkannya agar dapat diadili dengan hukum Indonesia maka aparat penegak hukum perlu menggunakan mekanisme Ekstradisi, sedangkan untuk mengembalikan asset-aset hasil dari korupsi maka menggunakan mekanisme Timbal Balik dalam Masalah Pidana atau yang biasa dikenal dengan istilah Mutual Legal Assistance in Criminal Matters (MLA). Mekanisme-mekanisme tersebut
\end{abstract}


menjadi sangat penting karena bagaimanapun dalam prinsip hukum internasional setiap negara memiliki kedaulatan atas wilayahnya, sehingga jika ingin masuk didalamnya dalam rangka pengekan hukum maka melalui mekanisme tersebut menjadi pilihan yang tepat.

\section{Kata kunci: Korupsi, Ekstradisi, Penegakan Hukum.}

\section{Pendahuluan}

Korupsi bagi Indonesia menjadi musuh utama untuk segera diatasi, saat ini tindak pidana korupsi tidak lagi menjadi persoalan nasional, bahkan telah menjadi persoalan transnasional, ini artinya persoalan ini tidak hanya terjadi di Indonesia. Dengan berbagai macam modus operandi yang digunakan seakan para pelaku tidak kehabisan jalan untuk melakukan kejahatan yang tergolong dalam extra ordinary crime (kejahatan luar biasa) ini. Faktor-faktor dominan sebagai penyebab terjadinya tindak pidana korupsi adalah faktor internal dari pelaku tindak pidana korupsi. Dari sisi manusia (internal pelaku) tindak pidana korupsi bisa terjadi karena kebutuhan (corruption by need), atau korupsi karena perilaku yang rakus (corruption by greed) atau mungkin korupsi karena terpaksa sehingga dipandang sebagai kecelakaan (corruption by accident) yaitu karena suatu sistem sehingga seseorang terpaksa terlibat dalam suatu perkara pidana. (Darmono, 2012: 137)

Berdasarkan Undang-Undang Nomor 31 Tahun 1999 sebagaimana diubah dengan Undang-Undang Nomor 20 tahun 2001 tentang Pemberantasan Tindak Pidana Korupsi, tidak terdapat secara harfiah mengenai definisi tindak pidana korupsi itu sendiri, namun dari hukum positif tersebut dapat disarikan 3 (tiga) makna dari tindak pidana korupsi yaitu : pertama, setiap orang yang secara melawan hukum melakukan perbuatan memperkaya diri sendiri atau orang lain atau suatu korporasi yang dapat merugikan keuangan negara atau perekonomian negara. (Pasal 2 ayat (1) UU Tipikor) Kedua, setiap orang yang dengan tujuan menguntungkan diri sendiri atau orang lain atau suatu korporasi, menyalahgunakan kewenangan, kesempatan, atau sarana yang ada padanya karena jabatan atau 
kedudukan atau sarana yang ada padanya karena jabatan atau kedudukan yang dapat merugikan keuangan negara atau perekonomian negara. (Pasal 3 UU Tipikor) Ketiga memberi hadiah atau janji kepada pegawai negeri mengingat kekuasaan atau wewenangnya yang melekat pada jabatan atau kedudukannya, atau oleh para pemberi hadiah atau janji dianggap melakat pada jabatan atau kedudukan tersebut. (Pasal 12 UU Tipikor).

Dari 3 (tiga) makna yang dijelaskan diatas, dapat ditarik sebuah kesimpulan, bahwa tindak pidana korupsi dapat berimbas pada kerugian keuangan negara dan perekonomian negara, sehingga implikasi yang diakibatkan secara tidak langsung dapat berdampak pada rakyat Indonesia secara umum, hal ini berbanding lurus dengan penggolongan tindak pidana korupsi sebagai salah satu extra ordinary crime, yang mengatasinyapun harus dengan cara-cara exstra ordinary pula.

Tindak pidana korupsi yang menjadi persoalan transnasioanal ini, pada perkembangannya banyak pelaku tindak pidana korupsi yang melarikan diri ke luar negeri untuk mengamankan dirinya maupun asetnya, maka diperlukan kerjasama internasional. Kerjasama ini menjadi salah satu bentuk tindakan agar kejahatan ini dapat diatasi secara menyeluruh dari hulu hingga hilir.

Indonesia menjadi salah satu negara yang ikut serta mengambil langkah untuk melawan tindak pidana korupsi ini dengan bersepakat bersama negara-negara lain untuk mengadakan kerjasama internasional, melalui badan-badan atau organisasi internasional dan menandatangani konvensi internasional anti korupsi yaitu United nation convention against Coruuption (UNCAC), yang kemudian diratifikasi oleh Indonesia dalam Undang-Undang Nomor 7 tahun 2006.

Tindakan yang diambil Indonesia ini sangat baik sebagai langkah pemberantasan tindak pidana korupsi yang semakin berkembang, salah satunya dengan melarikan diri ke luar negeri. Hal ini tentu menjadi langkah picik seorang koruptor untuk mengelabuhi aparat 
penegak hukum agar tidak dapat melakukan tindakan yang leluasa, mengingat dalam hukum Internasional berlaku prinsip penghormatan terhadap kedaulatan yuridiksi masing-masing negara, sehingga setiap negara luar yang memiliki kepentingan untuk masuk harus ada persetujuan terlebih dahulu, berdasarkan pula atas asas umum hukum internasional bahwa setiap negara memiliki kekuasaan tertinggi atas kedaulatannya.

Tentu demikian menjadi penghambat bagi penegakan hukum tindak pidana korupsi dan menjadi sebuah "keuntungan" bagi para pelaku korupsi. Guna mengatasi persoalan tersebut dan demi tegaknya hukum maka terdapat langkah Internasional yang dapat diambil yaitu dengan melakukan perjanjian Ekstradisi, sebagai bentuk komitmen masyarakat internasional untuk mengatasi kejahatan-kejahatan lintas batas negara. Ekstradisi merupakan penyerahan oleh suatu negara kepada negara yang meninta penyerahan seseorang yang disangka atau dipidana karena melakukan suatu kejahatan diluar wilayah negara yang menyerahkan dan di dalam yuridiksi wilayah negara yang meminta penyerahan tersebut, karena berwenang untuk mengadili dan memidananya. (Pasal 1 UU Ekstradisi).

Munculnya perjanjian ekstradisi ini tentunya tidak terlepas dari implementasi asas hukum internasional sebagaimana disampaikan oleh Hugo Grotius, yakni asas au dedere au punere. Yang artinya pengadilan terhadap pelaku kejahatan dapat dilakukan oleh negara tempat kejahatan itu terjadi atau diekstradisi kepada negara peminta yang memiliki yuridiksi untuk mengadili pelaku tersebut. (Syarifudin, 2016, p. 2) Ini artinya dengan asas tersebut para pelaku tindak pidana korupsi hanya dapat diadili di tempat ia melakukan tindak pidana, apabila pelaku melarikan diri ke negara lain, maka diperlukan perjanjian ekstradisi sebagai syarat untuk negara dapat melakukan tindakan terhadap pelaku yang malarikan diri tersebut.

Melihat peran ekstradisi kedepan sebagai hal yang krusial dalam penegakan hukum tindak 
pidana korupsi maka penulis tertarik untuk melakukan penelitian terkait dengan Efektifitas Ekstradisi Dalam Penegakan Hukum Tindak Pidana Korupsi Di Indonesia.

Berdasarkan latar belakang diatas, agar penulisan ini menjadi lebih terarah dan mencapai tujuan maka penulis mengemukakan perumusan masalah Bagaimana Peran Perjanjian Ekstradisi Dalam Penegakan Hukum Korupsi di Indonesia?

\section{Metode Penelitian}

Untuk memperoleh bahan hukum dan informasi yang kongkrit sebagai bahan dalam penulisan ini, maka metode yang digunakan adalah penelitian hukum normatif, yaitu penelitian yang dilakukan atau ditujukan pada peraturan tertulis dan bahan-bahan hukum lainnya baik yang bersifat sekunder yang ada di perpustakaan maupun jurnal hukum lainnya. Selain itu penelitian normatif juga melakukan kajian terhadap asas-asas hukum, sistematika hukum, taraf sinkronisasi hukum, sejarah hukum dan perbandingan hukum.
Sedangkan pendekatan masalah dalam penulisan ini dilakukan dengan mempergunakan metode pendekatan perundang-undangan (Statute Approach) yaitu pendekatan terhadap peraturan perundangundangan dengan menganalisa undang-undang dan regulasi yang berlaku mengenai isu hukum yang ditangani. (Marzuki, 2016: 137) dengan menelaah peraturan perundang-undangan yang ada dan regulasi terkait dengan persoalan yang menjadi objek penelitian.

Berdasarkan jenis penelitian yang bersifat normatif maka dalam mengumpulkan bahan hukum, penulis menggunakan metode pengumpulan data sekunder dengan melakukan studi kepustakaan, yang merupakan metode tunggal dalam penelitian hukum normatif.

Menganalisis penulisan ini menggunakan teknik bersifat sistematis dengan disajikan secara deskriptif-analitis, yaitu dengan mendeskripsikan bahan hukum terlebih dahulu secara sistematis kemudian menganalisa melalui teknik analisis dengan teknik tafsiran dan menggunakan argumentasi yang 
bertumpu pada logika hukum dengan deduktif-induktif.

\section{Ekstradisi}

Ekstadisi merupakan sebuah upaya dari suatu negara kepada negara lain agar negara tersebut menyerahkan orang yang dimaksud untuk diadili di negara yang memintanya. Syarat ekstradisi pada umumnya adalah kejahatan yang dilakukan merupakan kejahatan yang diakui oleh kedua negara. Ini artinya ada kesepahaman antar negara mengenai kejahatan apa yang dapat dilakukan ekstradisi, tentu hal ini melalui Perjanjian ekstradisi itu sendiri.

Dilainkan dari syarat kejahatan ekstradisi, kejahatan politik tidak termasuk didalamnya. Hal ini dikarenakan kejahatan tersebut bersifat subjektif dan dapat terjadi jika negara tersebut tingkat demokratisasinya sangat rendah. Ekstradisi ini dilakukan berdasarkan suatu perjanjian (treaty) antara negara satu dengan yang lainnya, dalam hal ini Indonesia misalnya, yang nantinya setelah melakukan perjanjian maka akan diratifikasi menjadi hukum nasional berbentuk Undang-Undang.

Terdapat pengecualian, bahwa ekstradisi ini dapat dilakukan tanpa didahului adanya perjanjian antar negara, namun didasarkan atas hubungan baik antar negara dan juga ketika kepentingan Indonesia dalam hal ini menghendakinya. (Pasal 2 (2) UU Ekstradisi)

Pada umumnya ekstradisi ini sebagai salah satu akibat dari hak asylum yaitu tujuan politik dan merupakan sarana untuk mencapai tujuan kekuasaan. Namun pada saat ini ekstradisi dipraktekan guna memasuki batas wilayah negara lain, dalam arti hukum pidana nasional dapat diterapkan terhadap para penjahat yang mekarikan diri ke negara lain. Hal ini dilakukan agar putusan pengadilan terhadap seseorang pelaku kejahatan yang melarikan diri ke luar negeri dapat dilaksanakan.

Dasar Hukum Ekstradisi penulis mengelompokan menjadi 2 (dua) bagian yaitu kelompok yang pertama adalah Perundang-Undangan Nasional. Pada kelompok ini sejarahnya Indonesia pada awal abad 
19 telah mengundangkan aturan terkait dengan Ekstradisi, dalam regulasi tersebut sebagian dari tujuan perumusannya dipengaruhi oleh keinginan untuk menyelamatkan kemerdekaan seseorang dan sebagian lagi oleh pandangan bahwa segala hukum pidana dan prosedur harus didasarkan pada perundangundangan. Dengan dasar pemikiran inilah kemudian lahir UndangUndang Nomor 1 Tahun 1979 tentang Ekstradisi.

Kelompok yang kedua adalah dasar Hukum Internasional. Lahirnya suatu ekstradisi dalam hubungan hukum internasional tentu diawali dengan adanya perjanjian internasional terkait dengan ekstradisi itu sendiri. Setelah menetapkan perjanjian ekstradisi, selanjutnya dilanjutkan dengan usaha membuat perjanjian atau konvensi untuk mengadakan keseragaman ekstradisi dan prosedrunya, yang terdiri dari perjanjian bilateral yang dilakukan oleh 2 (dua) negara, dan perjanjian multilateral dan konvensi yang dilakukan oleh lebih dari 2 (dua) negara.

\section{Tindak Pidana Korupsi}

Dalam Kamus Besar Bahasa Indonesia, korupsi secara harfiah berarti buruk, rusak, suka memakai barang (uang) yang dipercayakan padanya, dapat disogok (melalui kekuasaannya untuk kepentingan pribadi). Adapun arti terminologinya, korupsi adalah penyelewengan atau penggelapan (uang negara atau perusahaan) untuk kepentingan pribadi atau orang lain. (RI, 1955: 527) Sementara itu disisilain korupsi juga diartikan sebagai kebusukan, keburukan dan kebejatan. (Danil, 2011: 13) Pada intinya korupsi merupakan penyalahgunaan kepercayaan yang diberikan publik atau pemilik untuk kepentingan pribadi.

Dalam Undang-Undang Nomor 31 Tahun 1999 sebagai dirubah dengan Undang-Undang Nomor 20 Tahun 2001 tentang Pemberantasan tindak pidana korupsi tidak ditemukan pengertian secara harfiah mengenai tindak pidana korupsi, namun dalam uraian materi muatannya terdapat beberapa pasal yang dapat dijadikan sebagai rujukan untuk pemaknaan terhadap tindak 
pidana korupsi, diantaranya adalah Pasal 2, Pasal 3 dan Pasal 12.

Berdasarkan uraian dalam Undang-Undang aquo tindak pidana korupsi dapat dikelompokan menjadi beberapa bagian, dianatanya adalah (a). Kelompok tindak pidana yang dapat merugikan keuangan negara atau perekonomian negara. (b). Kelompok tindak pidana penyuapan, baik aktif (yang menyuap) maupun pasif (yang disuap) serta gratidikasi.

(c). Kelompok tindak pidana penggelapan. (d). Kelompok tindak pidana pemerasan dalam jabatan. (e). Kelompok tindak pidana pemalsuan. (f). Kelompok tindak pidana yang berkaitan dengan pemborongan, leveransir, dan rekanan.

Dari ke 6 (enam) pengelompokan tindak pidana korupsi ini hanya 1 (satu) yang terdapat unsur merugikan keuangan negara, sedangkan 5 (lima) diantaranya mengatur mengenai perilaku menyimpang dari penyelenggara negara atau pegawai negeri dan pihak swasta. (Gunawan, 2015: 30-31)
Tindak Pidana Korupsi Menurut

United Nations Convention Against Corruption (UNCAC).

UNCAC Tahun 2003 merupakan salah satu wujud persiapan dan kesungguhan dari banyak negara termasuk Indonesia dalam pemberantan tindak pidana korupsi. Pengesahan konvensi UNCAC pada tanggal 9 Desember tahun 2003 di meksiko bersama 137 negara lainnya menjadi bukti awal komitmen Indonesia dan negaranegara peserta untuk memperbaiki diri melalui pemberantasan tindak pidana korupsi.

Sebagai wujud keseriusan terhadap pemberantasan tindak pidana korupsi Indonesia meratifikasi konvensi aquo pada 21 Maret 2006 yang kemudian diikuti dengan disahkannya UndangUndang Nomor 7 Tahun 2006, adanya dukungan besar dari internasional melali konvesi ini pemerintah Indonesia berharap dapat mempercepat pemberantasan tindak pidana korupsi.

Adapun tujuan yang ingin di capai dari konvensi ini tertuang dalam Bab 1 tepatnya Pasal 1 The 
United Nations Convention Against

Corruption, sebagaimana berikut :

(a). Meningkatkan dan memperkuat upaya-upaya untuk mencegah dan memberantas tindak pidana korupsi secara lebih efisien dan efektif. (b). Meningkatkan, memfasilitasi, dan mendukung kerjasama internasional dan bantuan teknis dalam pencegahan dan pemberantasan tindak pidana korupsi, termasuk dalam pengambilan asset. (c). Meningkatkan integritas, akuntabilitas, dan pengelolaan yang baik dalam urusan-urusan publik dan kekayaan publik. (Gunawan, 2015: 12)

Dari tujuan tersebut sebagaimana tertera dalam poin (b), maka hal ini membuka peluang yang selebar lebarnya dengan adanya konvensi untuk masing-masing negara melakukan perjanjian internasional sebagai tindak lanjut dari konvensi.

Salah satu contohnya melalui perjanjian Ekstradisi yang memang fokus dalam pengembalian pelaku tindak pidana, tentu menjadi hal yang positif, karena dengan ini akan mempersempit ruang bagi para pelaku korupsi untuk melarikan diri baik dirinya maupun asetnya keluar negeri, dengan ini diharapkan agar kejahatan-kejahatan korupsi yang merugikan rakyat secara massif dapat segera teratasi dan semakin turun itensitasnya setiap tahunnya.

\section{Hasil dan Pembahasan}

Ekstradisi dan pemberantasan tindak pidana korupsi merupakan dua hal yang tidak bisa saling terpisahkan, melihat semakin tidak terkontrolnya pelaku korupsi di Indnonesia yang semakin cerdik dalam menutupi setiap tindak tanduk dalam melaksanakan kejahatan tersebut menjadi perhatian khusus.

Melarikan diri ke luar negeri, menghilangkan jejak dari bangsanya sendiri, seakan menjadi kebiasaan yang diulang-ulang para pelaku tindak pidana korupsi. Tujuannya tentu berharap tidak dapat terdeteksi dan dapat menghilangkan jejaknya untuk bebas dari segala macam tuntutan hukum nasional.

Langkah ini menjadi familiar untuk dilakukan, karena menjadi pilihan yang logis bagi para pelaku, meskipun negara memiliki perangkat 
yang cukup namun pelaku tidak kalah cerdiknya, mempersiapkan segalanya sebelum tindakan yang diambil oleh negara, tentu ini menjadi preseden buruk apabila negara sering didahului bertindak oleh para pelaku.

Namun negara-negara di dunia termasuk didalamnya telah mengambil langkah yang baik untuk mengatasi hal ini dengan ditandatanganinya UNCAC pada tahun 2003 yang kemudian di ratifikasi dalam Undang-Undang Nomor 7 Tahun 2006. Dalam pengesahan atas konvensi UNCAC tersebut ditegaskan bahwa tindak pidana korupsi merupakan ancaman terhadap pronsip-prinsip demokrasi, yang menjunjung tinggi transparansi, akuntabilitas, dan integritas, serta keamanan dan stabilitas bangsa Indonesia.

Sifat kejahatan korupsi yang sistemik dapat secara luas merugikan pembangunan bersifat berkelanjutan, sehingga memerlukan langkahlangkah pencegahan dan pemberantasan yang bersifat menyeluruh, sistematis, dan berkesinambungan baik pada tingkat nasional maupun internasional.

Melalui penegasan UNCAC diatas menandakan adanya kesepakatan Internasional atas bahaya laten korupsi terhadap negara secara keseluruhan, dan ini benarbenar terjadi hingga saat ini, dengan semakin tidak terkendalinya para pelaku tindak pidana korupsi yang justru melibatkan banyak pihak didalamnya, swasta, pegawai negara, hingga aparat penegak hukum itu sendiri sering terjerembab dalam lingkaran tersebut.

Oknum yang terlibat ini tentu bertujuan untuk memperkaya diri sendiri dengan cara yan salah, moral, etika serta prinsip-prinsip keagamaan seakan tidak lagi ada pada diri mereka.

Dengan tingat urgentsitas penanganan terhadap kasus tindak pidana korupsi ini maka diperlukan tindakan pencegahan dan pemberantasan tindak pidana korupsi yang efisien dan efektif namun hal ini harus dibarengi dengan dukungan tata manajemen pemerintahan yang baik dan kerjasama internasional, termasuk pengembalian aset yang 
berasal dari tindak pidana korupsi. (Bagian 1 Umum Penjelasan UU Nomor 7 Tahun 2006)

\section{Syarat dan Prosedur Ekstradisi}

Pelaksanaan ekstradisi tidak dapat begitu saja dilaksanakan, hal ini berkaitan dengan hak asasi manusia yang perlu untuk diperhatikan, terlepas disisi lain orang yang diminta untuk diekstradisi tersebut diduga telah melakukan suatu tindak pidana di negara peminta ekstradisi, sehingga perlu memperhatikan beberapa syarat ekstradisi yang telah ditentukan.

Sebelum suatu permohonan ekstradisi dikabulkan maka terlebih dahulu wajib dipenuhi syarat yang berkisar pada masalah pokok, (a). Oknum yang dapat dimintakan Ekstradisi, diantranya adalah oknum yang melakukan kejahatan disuatu negara dan tidak di negara dimana ia ditemukan dan oknum tersebut harus dicari oleh badan pengadilan suatu negara. (b). Keadaan yang dapat menjadi alasan dikabulkannya Ekstradisi yaitu Tindak pidana yang dilakukan itu harus merupakan tindak pidana biasa, artinya bukan tindak pidana politik. Karena tindak pidana tersebut tidak dapat diekstradisikan. Dalam hal ini yang dapat menentukan apakah suatu tindak pidana itu berbentuk politik diserahkan pada negara peminta. (b). Tindak pidana yang dilakukan itu termasuk salah satu dari tindak pidana yang disebutkan dalam perjanjian Ekstradisi yang bersangkutan. (c). Tindak pidana itu harus diancam oleh peraturan perundang-undangan kedua negara, yaitu negara peminta dan negara yang diminta Ekstradisi. (d). Tindak pidana tersebut sebelumnya tidak pernah diputus dahulu oleh Pengadilan terhadap tindak pidana yang sama, dan (e). Batas waktu yang ditentukan menurut undangundang yang berlaku pada negara peminta maupun negara yang meminta belum dilampaui.

Syarat-syarat Ekstradisi setiap negara secara garis besar tidak jauh berbeda dengan yang dijelaskan diatas, namun karena setiap negara memiliki yuridiksi masing-masing maka lebih detailnya mengenai syarat ekstradisi ini akan diatur 
dalam perundang-undangan masingmasing negara, contohnya Indonesia mengatur mengenai ekstradisi dalam Undang-Undang Nomor 1 Tahun 1979 tentang Ekstradisi, selain itu juga masing-masing negara dapat mengacu dalam perjanjian ekstradisi masing-masing negara.

Syarat-syarat Ekstradisi tersebut agar dapat dilaksanakan maka diperlukan adanya aturan sebagai prosedur yang harus dilalui dalam menuntut hak dan melaksanakan kewajiban bagi kedua belah pihak. Dilihat dari sumbernya, persoalan prosedur berasal dari tiga sumber, yaitu Perjanjian Ekstradisi itu sendiri, peraturan perundangundangan nasional masing-masing negara tentang Ekstradisi, dan peraturan hukum nasional lainnya khususnya peraturan hukum acara pidana yang berlaku juga untuk masalah Ekstradisi.

Prosedur yang bersumber pada hukum atau perjanjian Ekstradisi misalnya permintaan penyerahan dan syarat-syaratnya kepada lembaga, yang mana permintaan penyerahan harus diajukan, penahanan sementara orang yang diminta, penyerahan barang-barangnya serta proses penyerahan itu sendiri. Sedangkan prosedur yang bersumber pada hukum atau perundang-undangan nasional misalnya, lembaga atau pejabat yang berwenang menangkap menangkap si pelaku kejahatan serta menahan dan peraturan-peraturan hukum yang berlaku atas penahanan tersebut.

Prosedur Ekstradisi ini bukan merupakan persoalan hukum semata, tetapi juga menajadi kebijaksanaan pemerintah masing-masing negara. Dalam permohonan Ekstradisi diperlukan adanya suatu permohonan bagi negara negara yang diminta. Yang mana permohonan Ekstradisi tersebut disampaikan secara tertulis melalui jalur diplomatik, yang ditujukan pada kementerian luar negeri dari negara yang bersangkutan.

Berikut akan dijelaskan secara singkat bagaimana proses Ekstradisi baik ketika sebagai posisi peminta Ekstradisi maupun posisi penerima permohonan Ekstradisi. Proses Ekstradisi saat kedudukan Indonesia sebagai negara diminta, yaitu: diterimanya permintaan penahanan 
dan penangkapan, dilakukan

Peran Ekstradisi Dalam

penangkapan dan penahanan

Penegakan Hukum Tindak Pidana

sementara,

perpanjangan

Korupsi

penangkapan dan penahanan,

Penegakan hukum melalui

permintaan Ekstradisi, proses

proses ekstradisi merupakan proses

pemeriksan di pengadilan, proses

formal yang diserahkan oleh pengambilan keputusan dan pelaksanaan Ekstradisi.

Sedangkan proses Ekstradisi saat kedudukan Indonesia sebagai negara peminta, yaitu: permintaan pencarian sekaligus penangkapan dan penahanan, penyiapan persyaratan permintaan Ekstradisi, pemeriksaan permintaan oleh Mentri Hukum dan HAM, diperiksa dan di kirim secara formal oleh Menteri Luar Negeri kepada Negara Diminta (bagi yang telah memiliki Perjanjian), dikirim secara formal melalui saluran diplomatik NCBINTERPOL Negara-Diminta (bagi yang tidak memiliki Perjanjian), Pemeriksaan dipengadilan di Negara-Diminta, Putusan Pengadilan, disalurkan ke Menteri Kehakiman di Negara Diminta, pelaksanaan Ekstradisi.

(Nirmalananda, 2019: 20) seseorangan dari suatu negara kepada negara lain berdasarkan perjanjian yang ada antara negaranegara tersebut. Oleh karenanya, para pihak dalam proses itu sangat bergantung kepada prespektif penilaian mereka, mengenai individu yang menjadi objek dan subyek dari proses Ekstradisi.

Namun yang perlu diperhatikan oleh negara-negara yang mengikatkan diri dalam suatu perjanjian internasional adalah mengenai asas hukum diplomatik. Asas ini berpangkal pada suatu asas pada hukum romawi, yang diantaranya adalah suatu perjanjian atau persetujuan antar bangsa harus ditaati oleh peserta yang melakukan perjanjian, (Pratomo, 2011: 73) sehingga ada sebuah kewajiban bagi tiap negara untuk mlaksanakan isi dari perjanjian yang telah dibuat.

Perjanjian Ekstradisi menjadi salah satu cara untuk dapat masuk 
kedalam yuridiksi negara lain.

Hakekat dari penegakan hukum adalah seluruh tindakan, kebijakan, atau keputusan dari lembaga atau pejabat yang berwenang untuk dilaksanakannya ketentuan perundang-undangan dalam rangka penyelenggaraan kehidupan bermasyarakat, berbangsa dan bernegara. (Darmono, 2012: 137) upaya-upaya yang dilakukan seperti Ekstradisi ini merupakan satu langkah usaha penegakan hukum. Agar terjaminnya keadilan bagi rakyat Indonesia.

Ekstradisi merupakan salah satu hal yang penting dalam mencegah dan memberantas kejahatan didunia yang sedang dihadapi tidak hanya Indonesia karena semakin meningkatnya jumlah pelaku yang melarikan diri ke luar negeri. Dalam mengatasinya dibutuhkan kerjasama antar negara dengan perjanjian Ekstradisi sebagai penghubungnya. Dalam hubungan antar bangsa, Ekstradisi sebagai mekanisme antar bangsa dalam mencegah dan memberantas kejahatan kejahatan internasional. (Nirmalananda, 2019: 19) $\begin{array}{rrr}\text { Adapun } & \text { beberapa } & \text { contoh } \\ \text { pemerintah } & \text { Indonesia } & \text { telah }\end{array}$ melakukan beberapa permintaan Ekstradisi kepada negara lain, atas inisiatif dari tim terpadu pencari terpidana dan tersangka perkara tindak pidana korupsi, yaitu (a).Australia: Terpidana Hendra Raharja dan Adrian Kiki Ariawan, (b). Kanada: Terpidana Irawan Salim, (c). Inggris: Terpidana Rafat Ali Rizvi, (d). Saudi Arabia: Terpidana Hesham Al Warraq, (e). Vietnam: Terpidana Samadikun Hartono, (f). PNG: Terpidana Joko Soegiarto Tjandra, (g). Belanda: Tersangkak Maria Pauline Lumowa. Ini menandakan bahwa, efektifitas perjanjian ekstadisi dalam pemberantasan tindak pidana korupsi cukup optimal, sehingga menutup ruang para pelaku untuk melarikan diri keluar negeri, baik person nya, maupun aset-aset yang dimiliki

Namun masih terdapat beberapa catatan, berkaitan dengan proses pelaksanaan Ekstradisi, khususnya mengenai itensitas perumusan perjanjian Ekstradisi dengan negara lain. Hal ini ditunjukan dengan sedikitnya negara yang telah 
melaksanakan perjanjian Ekstradisi dengan Indonesia, berbanding terbalik dengan semakin banyaknya negara-negara yang dituju oleh pelaku tindak pidana korupsi untuk melarikan diri. Perjanjian Ektradisi ini sangat penting, mengingat terdapat beberapa negara didunia yang hanya mengabulkan permohonan Ekstradisi dari suatu negara hanya apabila negara tersebut telah melaksanakan perjanjian Ekstradisi. Tentu hal ini tidak bisa dibiarkan, mengingat semakin maraknya pelaku tindak pidana korupsi melarikan diri ke negara lain.

Terdapat pengecualian untuk tidak hanya melalui perjanjian Ekstradisi agar dapat melaksanakan proses Ekstradisi, namun dalam keadaan tertentu melalui hubungan baik antar negara dapat menjadi salah satu faktor untuk dilaksanakannya Ekstradisi, sehingga tidak mutlak melalui perjanjian Ekstradisi. Hal ini terjadi karena terdapat prinsip bahwa dalam hubungan internasional negara memiliki kedaulatannya masing-masing, meskipun terkadang kedaulatan ini menjadi penghalang dalam pencegahan, pemberantasan dan penghukuman pelaku kejahatan internasional maupun kejahatan yang berdimensi internasional. Namun secara formal Ekstradisi dapat dilakukan dengan perjanjian internasional, maupun hanya mengandalkan hubungan baik saja.

Indonesia pernah melakukan ekstradisi hanya dengan hubungan baik saja dengan Jerman, Indonesia sebagai negara peminta Ekstradisi dan Jerman sebagai pihak diminta Ekstradisi, (Nirmalananda, 2019: 20) ekstradisi ini kemudian dikabulkan dikarenakan telah memenuhi syarat dan tidak menyimpang dari prinsip dan kaidah yang harus diperhatikan. Ekstradisi ini dikabulkan berdasarkan pada hubungan baik antar negara.

Mensyaratkan atau tidaknya proses Ekstradisi dengan didahului perjanjian Ekstradisi dapat dilihat dari sistem hukum setiap negara. Dari sudut pandang common law system bahwa untuk semua aspek dari Ekstradisi diharuskan ada perjanjian Ekstradisi sebagai syarat utama untuk dapat disetujuinya permintaan negara-negara asing mengenai Ekstradisi ini. 
Sejak itu pula orang tidak dapat disetujui untuk diekstradisi jika tidak ada kewajiban berdasarkan aturan perundang-undangan atau perjanjian antar negara, dan ini dikuatkan dalam keputusan-keputusan pengadilan. Sebaliknya, negara-negara dengan civil law system menunjukkan kehendak yang lebih besar untuk menyetujui Ekstradisi walaupun tidak ada perjanjian antar negara. Menurut pandangan ini Ekstradisi didasarkan pada resiprositas. (Kalalo, 2016: 8)

Berdasarkan penjelasan diatas, menandakan bahwa sistem hukum suatu negara menjadi syarat yang benar-benar harus diperhatikan sebelum negara melakukan Ekstradisi dengan negara lainnya. Negara-negara dengan sistem hukum common law system mensyaratkan adanya suatu perjanjian atau peraturan perundang-undangan, sedangkan negara-negara dengan sistem hukum civil law system tidak mensyaratkan secara mutlak adanya perjanjian maupun peraturanperundangan untuk menjadi landasan dilakukannya Ekstradisi.
Kerapkali menjadi masalah adalah mengenai kemungkinan dijaminnya tersangka suatu kejahatan dari suatu negara untuk diserahkan kepada negara lain dalam hal tidak ada perjanjian antar negara mengenai Ekstradisi. Hampir semua negara maju dan sebagian besar negara berkembang merupakan pihak-pihak dalam perjanjian antar negara yang bersifat bilateral mengenai Ekstradisi.

Bagi negara itu yang undangundangnya atau praktek bakunya tidak membolehkan mereka melakukan Ekstradisi tanpa adanya suatu perjanjian internasional yang formal, maka perjanjian-perjanjian antar negara mengenai Ekstradisi adalah satu-satunya upaya yang dengan itu mereka bekerja sama dengan negara-negara lain dalam menyerahkan tersangka kepada jurisdiksi yang kompeten dalam mengadili mereka.

Jumlah dan efektifitas perjanjian-perjanjian demikian itu menjadi sangat penting. Bahkan bagi negara-negara yang perundang undangannya memungkinkan Ekstradisi tanpa ada suatu perjanjian 
antar negara, perjanjian perjanjian bilateral masih selalu diadakan sebagai yang penting untuk dasar Ekstradisi. (Kalalo, 2016: 9) Oleh banyak penulis, adanya suatu konvensi Ekstradisi dipandang sebagai yang paling ideal. Sementara itu perjanjian-perjanjian antar negara bersifat bilateral masih banyak diterapkan sebagai dasar utama Ekstradisi dalam praktek hukum internasional.

Melihat perkembangan pada akhir-akhir ini Ekstradisi dianggap menjadi proses satu-satunya yang sah dalam hal penyerahan seseorang yang sedang berada di negaranya terhadap negara lain, maka cara-cara lain selain Ekstradisi dianggap tidak sah. Anggapan demikian tidak dapat disalahkan menginat peranan Ekstradisi sangat fital, sebagai dasar suatu negara melakukan Ekstradisi terhadap pelaku tindak pidana korupsi yang sedang melarikan ke negara lain.

Prosedur atau proses dalam melakukan pengekstradisian atas si pelaku kejahatan, boleh dikatakan sangat panjang dan birokratis. Hal ini dirasakan sebagai hambatan yang cukup berat, terutama oleh para pelaksana di lapangan yang pada umumnya menghendaki supaya proses penangkapan ataupun penghukuman si pelaku kejahatan semacam itu bisa berlangsung dengan lebih cepat dan singkat, mengingat tugas-tugas mereka di lapangan yang cukup banyak dan sangat kompleks sifatnya.

Pelaku kejahatan yang diserahkan oleh suatu negara kepada negara lain melalui prosedur Ekstradisi biasanya adalah pelaku kejahatan yang berskala besar, yang menjadi perhatian dan sorotan dari seluruh atau sebagian besar masyarakat internasional.

Sedangkan untuk pelaku kejahatan yang tidak begitu menarik perhatian masyarakat internasional, meskipun mungkin memenuhi kualifikasi dari perjanjian tentang Ekstradisi, diselesaikan tidak melalui prosedur dalam perjanjian Ekstradisi.

Perjanjian Ekstradisi kini lebih merupakan menara gading ketimbang sebagai sarana kerja sama dalam pencegahan, pemberantasan, dan penghukuman pelaku kejahatan internasional ataupun pelaku 
kejahatan yang berdimensi internasional. Jika demikian halnya, maka timbul pertanyaan, upaya apakah yang efektif dalam mencegah, memberantas dan menghukum pelaku kejahatan semacam itu.

Prosedur Ekstradisi yang ketat, panjang, dari birokratis ini, diterobos dengan upaya hukum lain yaitu deportasi ataupun kerja sama antar kepolisian secara bilateral ataupun melalui lembaga Interpol. (Kalalo, 2016: 11-12)

Kendala-kendala dalam pelaksanaan Ekstradisi pelaku tindak pidana korupsi yang melarikan diri keluar negeri disebabkan oleh beberapa faktor, diantaranya adalah : (Poliando, 2019: 154) (a). Tidak adanya kerjasama internasional international criminal police organization (ICPO) Interpol pemerintah republik Indonesia dengan pemerintah negara tempat dimana pelaku tindak pidana korupsi tersebut melarikan diri. (b). Kerjasama lintas instansi intern di Indonesia yang berjalan tidak baik, dimana beberapa persyaratan yang harus dipenuhi oleh pihak kepolisian untuk dapat dilakukan Ekstradisi terlambat untuk dipenuhi oleh instansi yang berwenang di Indonesia seperti kejaksaan, KPK yang tidak responsif dalam memenuhi persyaratan yang dibutuhkan. Hal ini mengakibatkan terhambatnya pelaksanaan Ekstradisi tersebut oleh pihak kepolisian Republik Indonesia di negara tempat pelaku tindak pidana korupsi tersebut melarikan diri. (c). Pengaruh geostrategis dan geopolitik Indonesia sebagai bargaining power negara dalam memandang dan menyikapi terhadap pelaku tindak pidana yang melarikan diri ke luar negeri.

Sedangkan solusi yang harus dilakukan oleh pemerintah Republik Indonesia dalam pelaksanaan proses hukum terhadap pelaku tindak pidana korupsi yang melarikan diri ke luar negeri adalah : (Poliando, 2019: 154) (a). Memperbanyak kerjasama Internasional ICPO Interpol dengan negara -negara lain di bidang Ekstradisi, sehingga pemerintah Indonesia dapat melakukan proses Ekstradisi pelaku tindak pidana korupsi yang melarikan diri ke negara-negara 
tersebut. (b). Melakukan reformasi lembaga yang menangani permasalahan Ekstradisi yang ada di Indonesia dengan melibatkan instansi - instansi terkait yang memiliki kewenangan dalam melaksanakan legalisasi persyaratan yang diminta oleh negara -negara internasional tersebut untuk memperlancar proses Ekstradisi yang dilakukan oleh pihak kepolisian Republik Indonesia di negara tempat dimana pelaku tindak pidana korupsi tersebut melarikan diri, seperti misalnya instansi kepolisian, kejaksaan, Kementerian Hukum dan HAM, imigrasi dan kementerian luar negeri Republik Indonesia. (c). Membina hubungan diplomatik yang lebih baik dengan negara -negara yang belum memiliki perjanjian kerjasama internasional ICPO interpol dengan negara Indonesia, dengan tujuan meskipun belum memiliki perjanjian kerjasama internasional dengan negara -negara tersebut namun karena hubungan diplomatik yang baik antara pemerintah Indonesia dengan negara-negara tersebut maka proses Ekstradisi dapat saja dilaksanakan tanpa adanya terlebih dahulu ratifikasi perjanjian kerjasama internasional ICPO interpol tersebut Selain langkah Ekstradisi terdapat langkah lain yang biasa diambil dalam rangka penegakan hukum tindak pidana korupsi yang melarikan diri ke luar negeri, yaitu mutual legal assistance in criminal matter (MLA) atau bantuan timbal balik dalam masalah pidana. Yang diatur dalam Undang-Undang Nomor 1 Tahun 2006.

Tindakan MLA ini dapat berupa mengidentifikasi dan mencari orang, menunjukan dokumen, mengupayakan kehadiran orang untuk memberikan keterangan atau membantu penyidikan, menyampaikan surat, melaksanakan permintaan penggeledahan dan penyitaan, perampasan dasil tindak pidana, serta melarang transaksi kekayaan termasuk membekukan aset yang dapat dilepaskan atau disita. (Darmono, 2012: 138)

Yang perlu digaris bawahi adalah tindakan MLA ini tidak memberikan wewenang untuk penangkapan, penahanan dengan tujuan untuk menyerahkan orang. 
Sehingga negara tidak dapat meminta seseorang untuk diserahkan kepadaNya untuk diadili di negara dimana pelaku tindak pidana melakukan kejahatannya. Disinilah letak perbedaan antara Ekstradisi dengan MLA. Namun terdapat kesamaan dalam proses antara keduanya, baik MLA maupun Ekstradisi dapat dilakukan berdasarkan perjanjian antar negara sebelumnya maupun berdasar pada hubungan baik antar negara berdasarkan prinsip resiprositas.

Ada beberapa contoh proses MLA berupa pengembalian asset yang pernah dilakukan Indonesia dengan beberapa negara, diantaranya : (Darmono, 2012: 138) (a). Pengembalian Aset ECW Neloe (Bank Mandiri) sebesar kurang lebih USD 5.200.000,- (b). Permintaan MLA atas asset Bank Century di Swiss. (c). Permintaan MLA atas asset Bank Century di Hongkong.

\begin{tabular}{llr}
\multicolumn{1}{c}{ Deretan } & contoh & diatas \\
menandakan & bahwa & proses \\
Ekstradisi dan MLA & secara \\
konseptual dapat dijalankan secara \\
beriringan, hal ini menunjukan \\
bahwa proses Ekstradisi dilakukan
\end{tabular}

untuk menjamin tegaknya keadilan dan hukum Indonesia, sedangkan proses MLA dilakukan untuk mengembalikan aset-aset negara yang berada di negara lain, kedua proses bilateral ini jika dijalankan secara optimal, maka baik penegakan hukum dan pelindungan aset negara dapat ditegakan dan dilindungi secara maksimal.

Perjanjian Ekstradisi sebagai salah satu instrument hukum internasional untuk suatu negara dapat masuk dalam kedaulatan negara lain, dengan tujuan meminta penyerahan pelaku tindak pidana agar dapat diadili dengan hukum nasional negara pemohon Ekstradisi. Peranan perjanjian ekstradisi sangat sentral mengingat pelaku tindak pidana korupsi di Indonesia semakin maraknya melarikan diri ke luar negeri untuk menghilangkan jejak.

Melalui perjanjian Ekstradisi negara Indonesia tidak lagi terhalang-halangi dengan kedaulatan negara lain untuk dapat menegakan hukum bagi pelaku tindak pidana korupsi. Ekstradisi pelaku tindak pidana korupsi tidak hanya dapat dilakukan melalui perjanjian, namun 
dengan itikad baik antar negara dapat dijadikan sebagai landasan dilaksanakannya ekstradisi.

Selain perjanjian Esktradisi sebagai bentuk tindakan penyerahan pelaku tindak pidana korupsi kepada Indonesia, melalui mekanisme mutual legal assistance in criminal matter (MLA) Indonesia juga dapat mengembalikan aset negara yang dibawa keluar negeri oleh para pelaku tindak pidana korupsi, sehingga langkah untuk penegakan hukum bagi para pelaku tindak pidana korupsi yang melarikan diri ke luar negeri dapat dilakukan baik dengan Pejanjian Esktradisi maupun MLA.

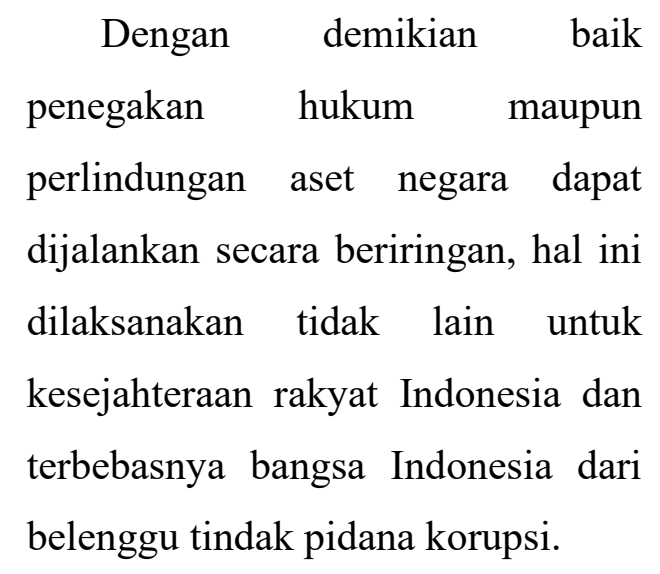

\section{Simpulan}

Peran Perjanjian Ekstradisi Dalam Penegakan Hukum Korupsi di Indonesia sangat penting.
Mengingat, bahwa persoalan dan tantangan dalam penegakam hukum tindak pidana korupsi di Indonesia adalah dengan semakin meningkatnya presentase kejahatan tersebut. Kemudahan dalam berpindah antar negara pelaku tindak pidana korupsi baik yang berstatus tersangka, terdakwa ataupun terpidana sering kali memilih untuk melarikan diri keluar negeri beserta asset-aset hasil korupsi yang dimilikinya. Oleh karena itu dalam rangka penegakan hukum bagi pelaku dengan cara memulangkannya agar dapat diadili dengan hukum Indonesia maka aparat penegak hukum perlu menggunakan mekanisme Ekstradisi, sedangkan untuk mengembalikan asset-aset hasil dari korupsi maka menggunakan mekanisme Timbal Balik dalam Masalah Pidana atau yang biasa dikenal dengan istilah Mutual Legal Assistance in Criminal Matters (MLA). Mekanisme-mekanisme tersebut menjadi sangat penting karena bagaimanapun dalam prinsip hukum internasional setiap negara memiliki kedaulatan atas 
wilayahnya, sehingga jika ingin masuk didalamnya dalam rangka pengekan hukum maka melalui mekanisme tersebut menjadi pilihan yang tepat.

\section{Saran}

Karena peran perjanjian Ekstradisi yang sangat fital dalam penegakan hukum tindak pidana korupsi, dan tidak menutup bahwa masih banyak kekurangan yang harus diperbaiki agar proses penegakan hukum dapat berjalan dengan baik, maka penulis menyarankan beberapa hal, diantaranya : (a). Proses ekstradisi yang masih panjang dan birokratis sebagai salah satu penghambat, maka perlu disikapi dengan upaya hukum lain yaitu deportasi ataupun kerja sama antar kepolisian secara bilateral ataupun melalui lembaga Interpol, sebagai langkah lain jika proses Ekstradisi menemui jalan buntu. (b). Peraturan perundang-undangan Indonesia baiknya segera menerbitkan Peraturan pemerintah sebagai peraturan pelaksana dari Undang-Undang No,1 Tahun 1979 tentang Ekstradisi, sehingga norma yang tidak diatur dalam undangundang aquo dapat diimplementasikan dalam Peraturan Pemerintah tersebut.

\section{Daftar Pustaka}

\section{Buku}

Pratomo, Eddy, 2011, Hukum Perjanjian Internasional : Pengertian, Status Hukum dan Ratifikasi, Bandung : Alumni.

Danil, Elwi, 2011, Korupsi Konsep, Tindak Pidana dan Pemberantasannya, Jakarta : Rajawali Pers.

Kristian dan Gunawan, Yopi, 2015, Tindak Pidana Korupsi (Kajian terhadap Harmonisasi antara Hukum Nasional dan United Nations Convention Against Corruption(UNCAC).Band ung : Refilka Aditama.

Marzuki, Mahmud, Peter, 2016, Penelitian Hukum, Surabaya : Prena Meda Group.

\section{Jurnal}

Darmono, 2012, Ekstradisi Terpidana Kasus Korupsi dalam Rangka Penegakan Hukum Tindak Pidana Korupsi, Jurnal Lex Jurnalica, Volume 9 Nomor 3. 
Syarifudin, 2016, Relevansi UndangUndang Nomor 1 Tahun 1979 tengan Ekstradisi dengan Perkembangan Hukum Ekstradisi Internasional, Jurnal Hukum, Volume 2 Nomor 1.

Dwi Melia Nirmalananda dkk, 2019, Ekstradisi Sebagai Upaya Pencegahan dan Pemberantasan Kejahatan Internasional, Jurnal Analogi Hukum, Volume 1 Nomor 1.

Flora Pricilla Kalalo, 2016, Efektifitas Perjanjian Ekstradisi Sebagai Sarana Pencegahan, Pemberantasan dan Penghukuman Pelaku Tindak Pidana Internasional, Jurnal Lex et Societatis, Volume IV Nomor1.

Dio Poliando Panggabean, 2019, Ekstradisi Pelaku Tindak Pidana Korupsi yang Melarikan Diri Keluar Negeri oleh Kepoliasian Negara Republik Indonesia berdasarkan Ketentuan Hukum International Criminal Police Organization (ICPO/Interpol), USU Law Journal, Volume7 Nomor 6.

\section{Perundang-undangan}

Undang-Undang Nomor 1 Tahun 1979 tentang Ekstradisi.

\author{
Undang-Undang Nomor 31 Tahun \\ 1999 sebagaimana diubah \\ dengan Undang-Undang \\ Nomor 20 Tahun 2001 \\ tentang Pemberantasan \\ Tindak Pidana Korupsi.
Undang-Undang Nomor 7 tahun 2006 tentang Pengesahan United Nations Convention Against Corruption (UNCAC). \\ Undang-Undang Nomor 24 Tahun \\ 2004 tentang Perjanjian \\ Internasional.
}

